\title{
Developing Indonesian Learning Game Applications for Elementary School Students Using the Prototyping Method
}

\author{
Chamdan Mashuri ${ }^{1}$, Rusli Ilham Fadli ${ }^{2}$, Ginanjar Setyo Permadi ${ }^{3}$, Ahmad Heru Mujianto ${ }^{4}$ \\ ${ }^{1,4}$ Department of Information Systems, Faculty of Information Technology, University of Hasyim Asy'ari, \\ Indonesia \\ ${ }^{2}$ Department of Indonesian Language and Literature, Faculty of Education, University of Hasyim Asy'ari, \\ Indonesia \\ ${ }^{3}$ Department of Information Management, Faculty of Information Technology, University of Hasyim Asy'ari \\ Indonesia
}

\section{Corresponding Author:}

Chamdan Mashuri,

Department of Information Systems, Faculty of Information Technology, University of Hasyim Asy'ari, Indonesia,

J1. Irian Jaya No 55 Tebuireng, Jombang, East Java, Indonesia.

Email: chamdan.mashuri@gmail.com

Article History: Received:11 January 2021; Accepted: 27 February 2021; Published online: 5 April 2021

\begin{abstract}
Indonesian Language Lessons are lessons that must be given in the world of education ranging from basic education to higher education. The problem that is currently emerging is that Indonesian language lessons are less attractive and less attractive to students in elementary schools. The purpose of this research is to develop an application of Indonesian language learning games for elementary school students with the Android Game-based prototyping method as a medium for learning Indonesian lessons in elementary schools to make it more interesting, and to help make it easier for students to understand Indonesian lessons well in the hope of making an educational atmosphere. interesting, fun, comfortable and can increase the value of students. The prototyping method is a software development method, in the form of a physical working model of the system and functions as an early version of the system. With this prototyping method, a system prototype will be produced as an intermediary for developers and users so that they can interact in the process of information system development activities. In order for the prototype making process to be successful, it is by defining the rules at an early stage, that is, the developer and the user must have an understanding that the prototype is built to define initial requirements. The prototype will be removed or added to its part so that it is in accordance with the planning and analysis carried out by the developer until the trial is carried out simultaneously along with the development process.
\end{abstract}

Keywords:Learning Media, Indonesian, Elementary School, Games Prototyping

\section{INTRODUCTION}

Information technology is developing very rapidly so that it has a big influence on the world of education in Indonesia. As with information, from time to time there will be an increase in information needs. For this reason, education must now have a strategy to facilitate learning activities, namely by having technology-based learning media that is applied to mobile platforms for learning elementary school (SD) students.

Indonesian Language lessons are lessons that must be given in the world of education starting from basic education to higher education. The problem that has been emerging lately is that Indonesian language lessons are less attractive and become less attractive lessons for students in elementary schools, on the other hand, the media and teaching aids for Indonesian Language Lessons in elementary schools are still minimal and classified as primitive.

Research relevant to the topic "Educational Games as Learning Media for Early Childhood Education" with the results of the research that educational games are very interesting to develop, there are several advantages of educational games compared to conventional educational methods, one of the main advantages of educational games is the visualization of real problems. . Based on the pattern that the game has, players are required to learn so that they can solve existing problems. Game status, instructions, and tools provided by the game will actively guide players to dig up information so that they can enrich their knowledge and strategies while playing. The purpose of this research is to make a mobile game application as an alternative medium of learning to recognize symbols, count, match pictures and compose random words. This game can be used as an alternative medium for Early Childhood Education (PAUD) teacher learning in changing conventional learning methods into game 
simulation learning methods, so as to develop children's creativity, because in educational games it has elements of challenge, accuracy, reasoning and ethics (Vitianingsih, 2016).

Research has been carried out "Information Technology-Based Learning Media Development" which resulted in the conclusion that learning media can be a vehicle for channeling messages and learning information. Learning media that are well designed will greatly help students digest and understand the subject matter. The function of the media in learning activities is not just a teaching aid for the teacher but as a carrier of learning information / messages. Each type of learning media has its characteristics, advantages and disadvantages. That is why it is necessary to have a systematic planning for the use of instructional media. In this era of globalization and information, the development of learning media is also progressing. The use of Information Technology (IT) as a learning medium is already a requirement. Although IT-based media design requires special skills, this does not mean that the media is avoided and abandoned. IT-based learning media can be in the form of internet, intranet, mobile phone, and CD Room / Flash Disk. The main components include the Learning Management System (LMS) and Learning Content (LC). The use of economic learning media can facilitate the learning process and optimize learning outcomes for that, as educators should be able to choose and develop the right media so that the learning process can run more effectively and efficiently (Muhson, 2010).

Other research relevant to the title "Prototyping Model in Information System Development" with the results of research that requires careful planning in planning and development of systems and planning starting from good system design, personnel selection, determination of software and hardware, and network architecture commitment. between the developer, the user, and the leader of the organization (Purnomo, 2017). some users have difficulty expressing their desire to get an application that suits their needs. \& this difficulty needs to be resolved by analysts by understanding user needs and translating them into prototypes. This model is then continually improved until it is according to user needs. The application of the system is important for the information system developer in assessing the success of the information system whether it runs according to the plan and whether it has fulfilled the wishes of its users. Unclear planning and analysis often creates problems that will affect development activities. This study will provide an overview of the use of prototyping models in information system development activities in the hope of producing a prototype as one of the first steps in developing an information system. Protype is created with the aim of providing equal perception and initial understanding of the basic processes of the system to be developed, so that there will be good communication between developers and system users (Susanto and Meiryani, 2019).

The present study examines different prototyping approaches in software development. There are researched different variations of so-called "prototyping model "The paper examines the prototyping process as problem solving process and makes reference to process approach. The aim of this paper is to propose a prototyping approach in user interface development based on evolutionary prototyping approach and process approach (Nacheva, 2017).

From previous relevant and existing research studies, this study builds a game with a prototyping method with the unity application and focuses on game content based on the Indonesian curriculum as material for the content of the game.

\section{RESEARCH METHOD}

To achieve the goal of this research, there are several stages as shown in the picture above, and the researchers will explain as follows.

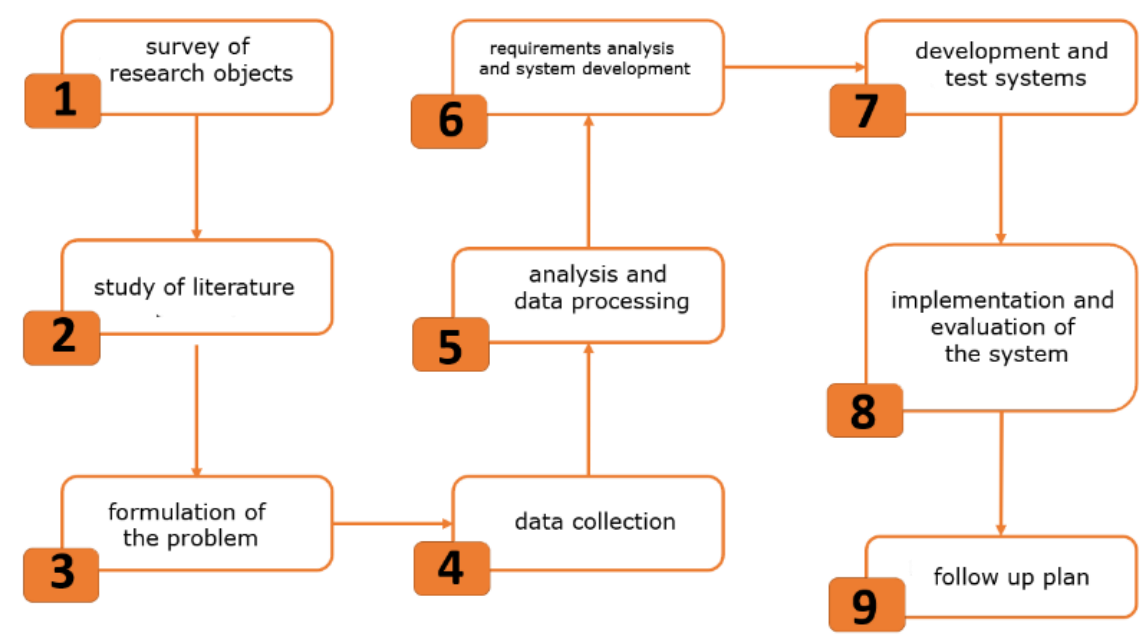

Figure 1. Research flow 
The research flow explains the first step, namely the field survey directly to elementary schools (SD) to store learning data and educational activities as well as the complexity that occurs. Furthermore, a literature study is carried out to understand the processes that occur in schools and the appropriate methods to solve existing problems. The next step is the formulation of the problem to determine the criteria for the problem in order to find the appropriate method for the problems that occur. Data collection and data analysis in order to determine the application framework, create designs and interfaces, compile in-game curricula and analyze patterns of students. The next step is needs analysis and system design which is the first step in the software development life cycle, at this stage it will produce specifications and requirements that will be owned by the software to be developed taking into account all user needs. Needs analysis is divided into two, namely functional and non-functional requirements. Functional requirements contain what processes or services the system will provide. Meanwhile, non-functional needs are those that focus on the behavioral properties of the system. System development and testing is an important step which is an advanced stage of design and design results, which is then carried out by the development or development process of the system according to the results of the analysis and design of the system. system development until the beginning to the end which is directly tested or the testing system, the testing system is carried out by testing the system flow and the source code system. The final stage is the implementation of the system to users.

\subsection{Development using prototyping method}

Prototyping is a system development process often using a prototype approach. This method is very well used to solve the problem of misunderstanding between the user and the analyst that arises due to the user being unable to clearly define his needs. Prototyping is the rapid development and testing of working models (prototypes) of new applications through an interaction and repetitive process that is commonly used by information system experts and business experts. Prototyping is also called rapid application design (RAD) because it simplifies and speeds up system design (Susanto and Meiryani, 2019).

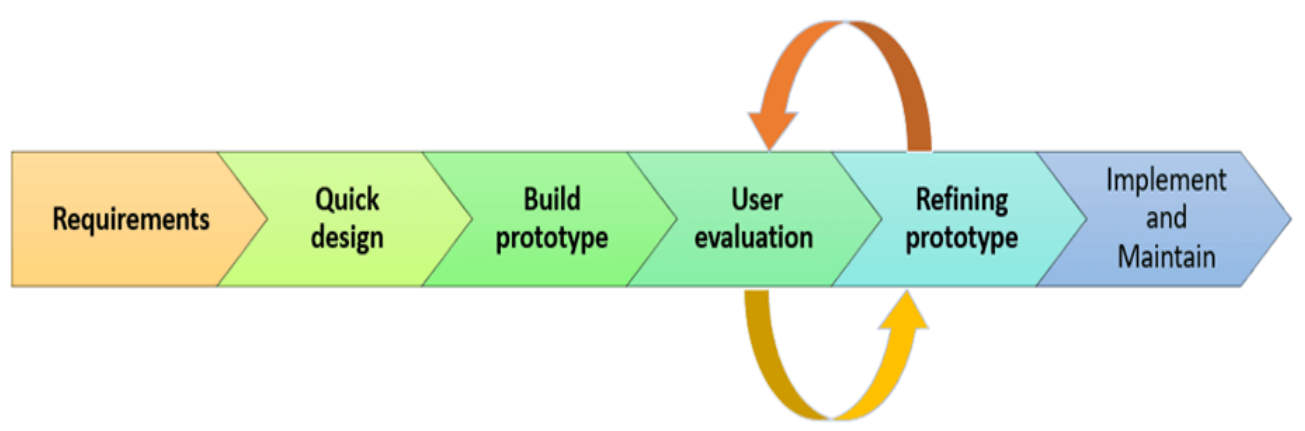

Figure 2. Prototyping model phases

\section{Requirements gathering and analysis}

A prototyping model starts with requirement analysis. In this phase, the requirements of the system are defined in detail. During the process, the users of the system are interviewed to know what is their expectation from the system. System requirements analysis defines system requirements in the form of System input, ystem output, Processes running in the system, The database used, the right software and the desired interface.

\section{Quick design}

The second phase is a preliminary design or a quick design. In this stage, a simple design of the system is created. However, it is not a complete design. It gives a brief idea of the system to the user. The quick design helps in developing the prototype. 


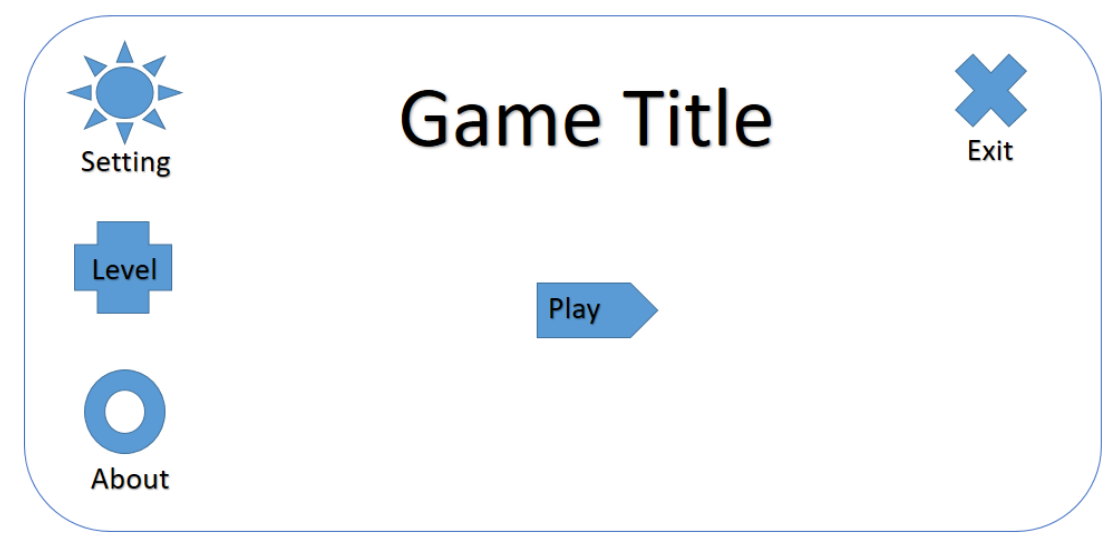

Figure 3. Main menu page

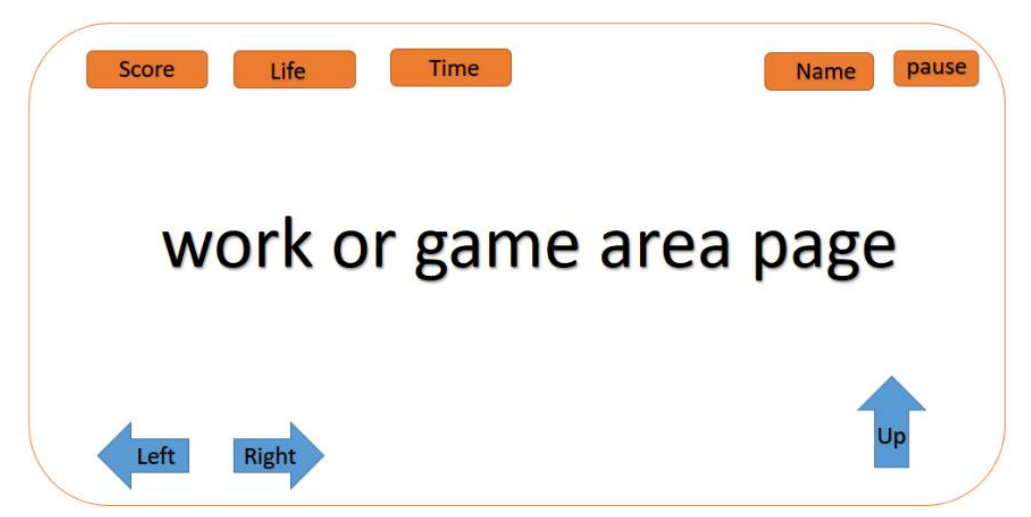

Figure 4. The main page of the game area

\section{Build a Prototype}

In this phase, an actual prototype is designed based on the information gathered from quick design. It is a small working model of the required system.

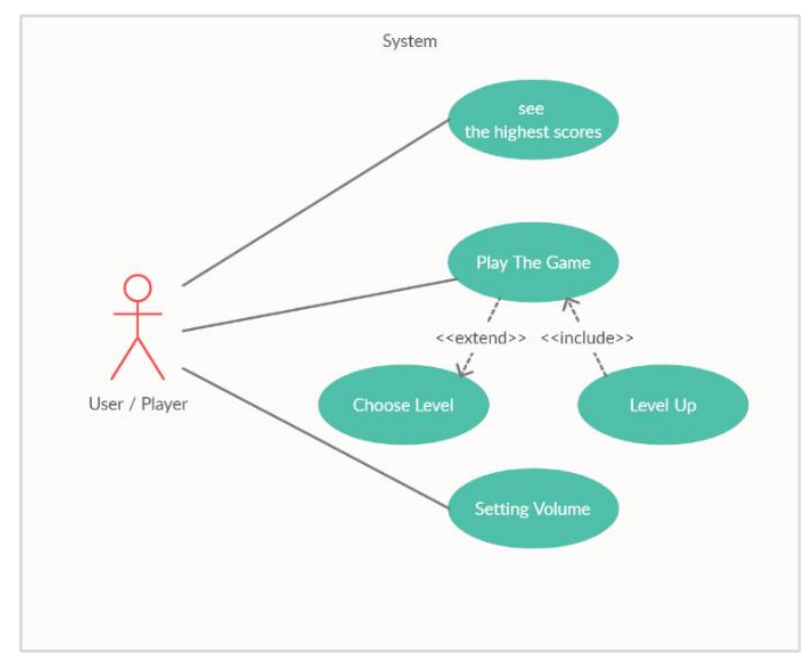

Figure 5. The Use case diagram game 
Developing Indonesian Learning Game Applications for Elementary School Students Using the Prototyping Method

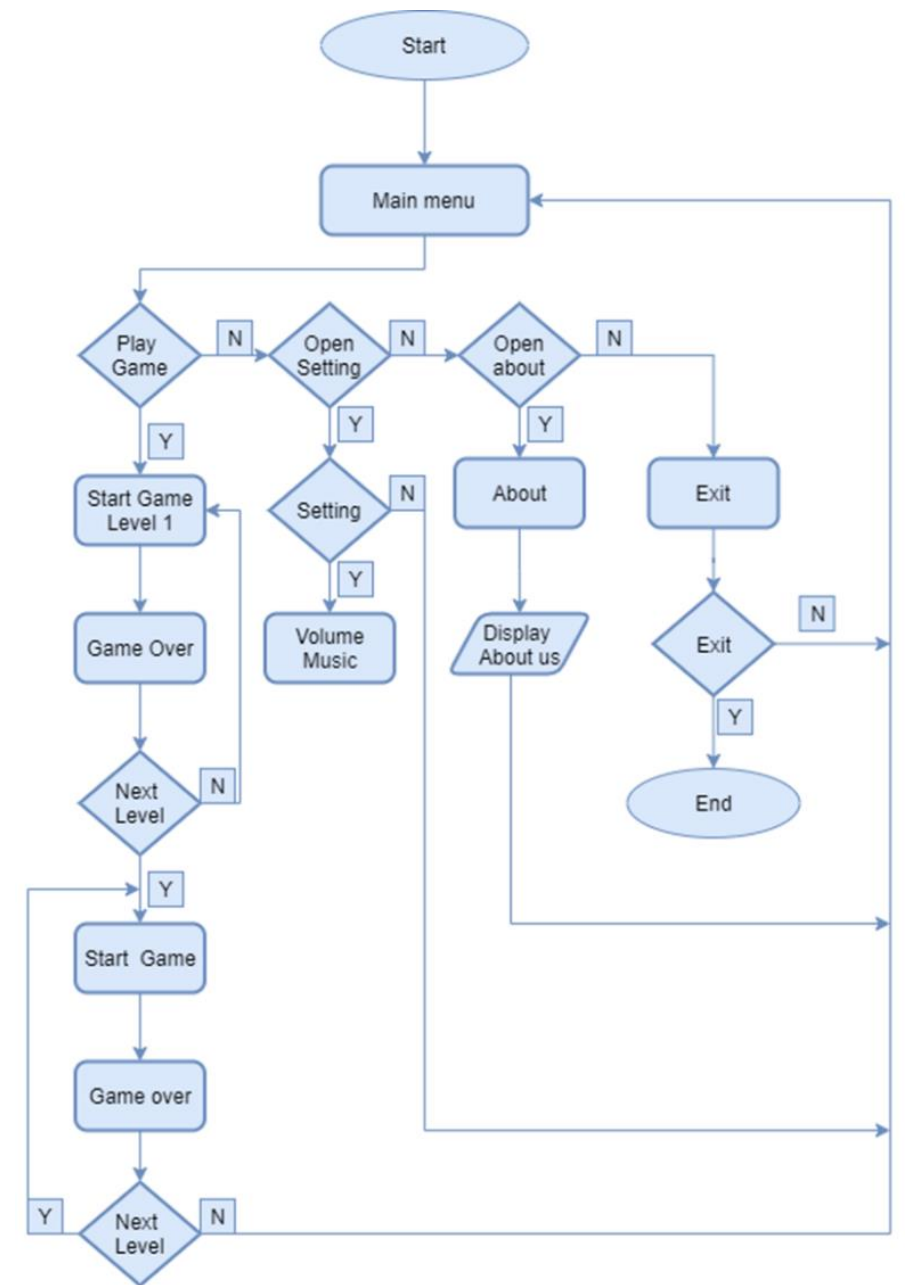

Figure 6. The flowchart game

\section{RESULTS AND DISCUSSION}

Based on the design, design and manufacture stages that have been done, an android game has been produced. The game has dimensions of $1280 \times 720$ pixels. with a speed of 60 frames per second. The results of this game design can be seen in the form of the start page view, game view and page view when the game ends. The initial display of the game is shown in Figure 7.

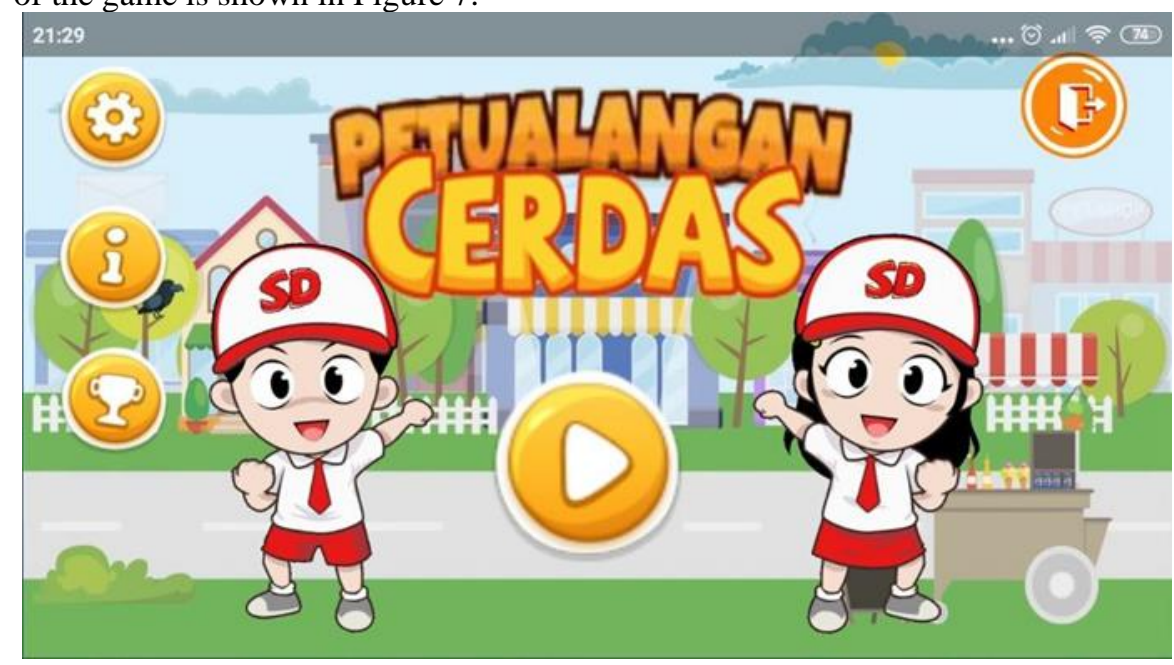

Figure 7. Homepage

When the game is first opened, it will display a start page that looks like Figure 7 above, which consists of 5 button choices, namely: 
a. Setting Button

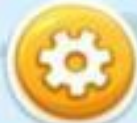

This button is used to adjust the game volume, and its appearance is as shown in Figure 8.

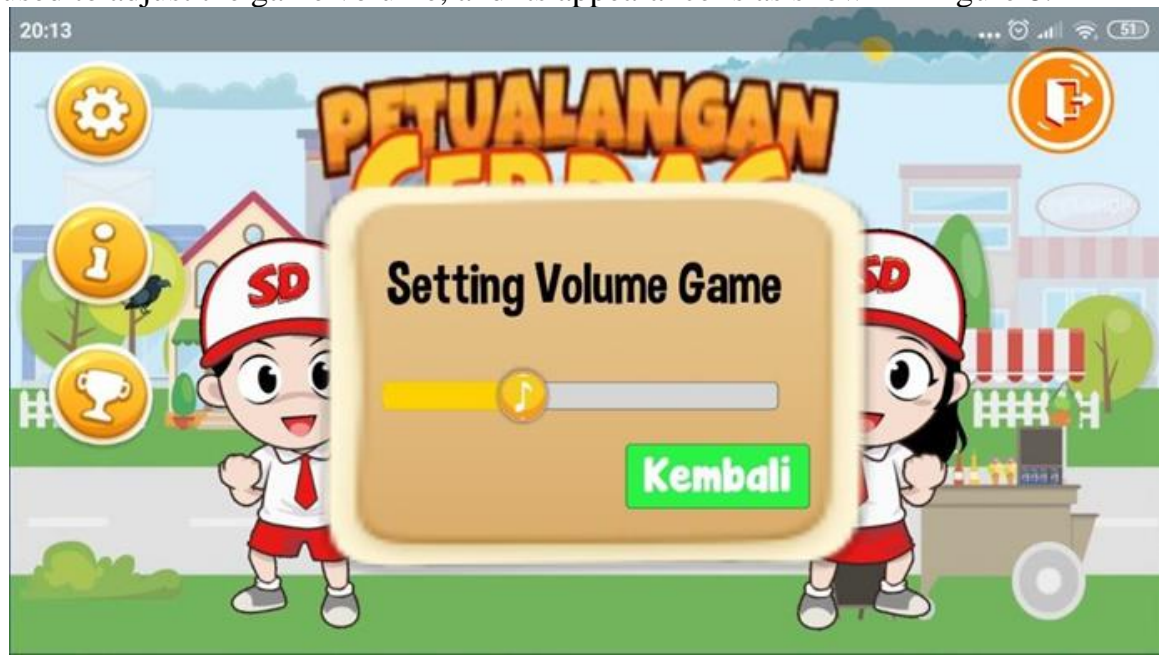

Figure 8. Setting page

b. Information button

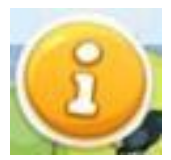

This button is used to provide information on the game development team, and its appearance is as shown in Figure 9.

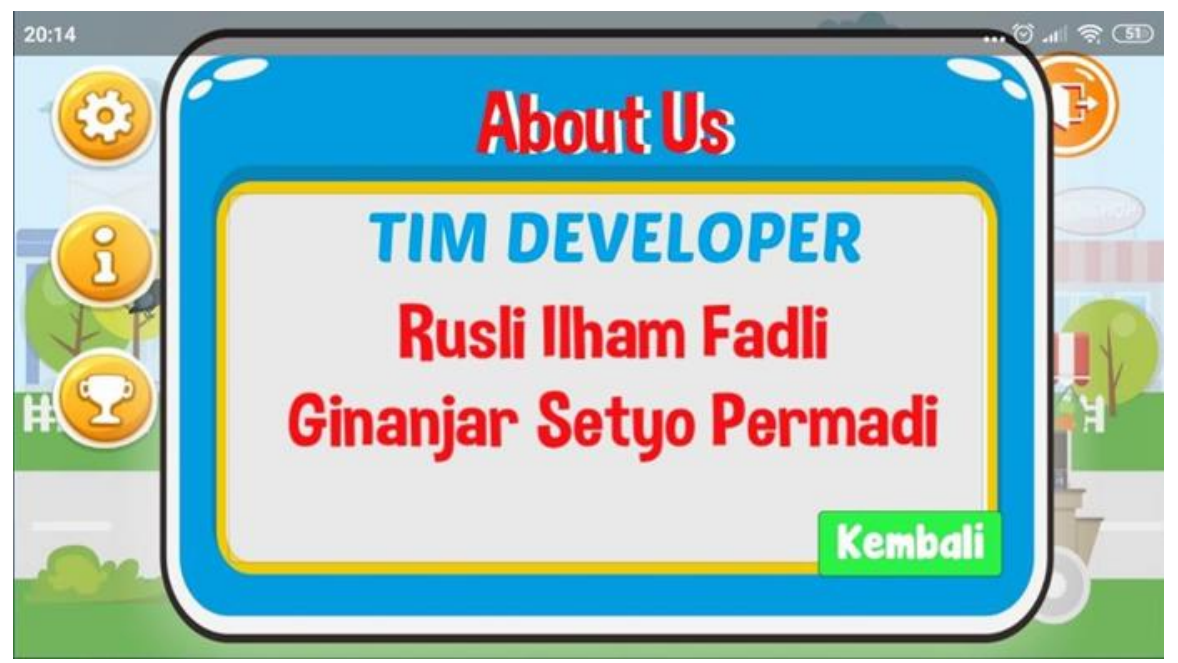

Figure 9. Information Button

c. Tropy button

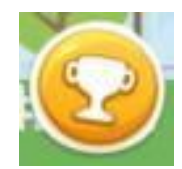


Developing Indonesian Learning Game Applications for Elementary School Students Using the Prototyping Method

This button is used to provide game score information, and its appearance is as shown in Figure 10.

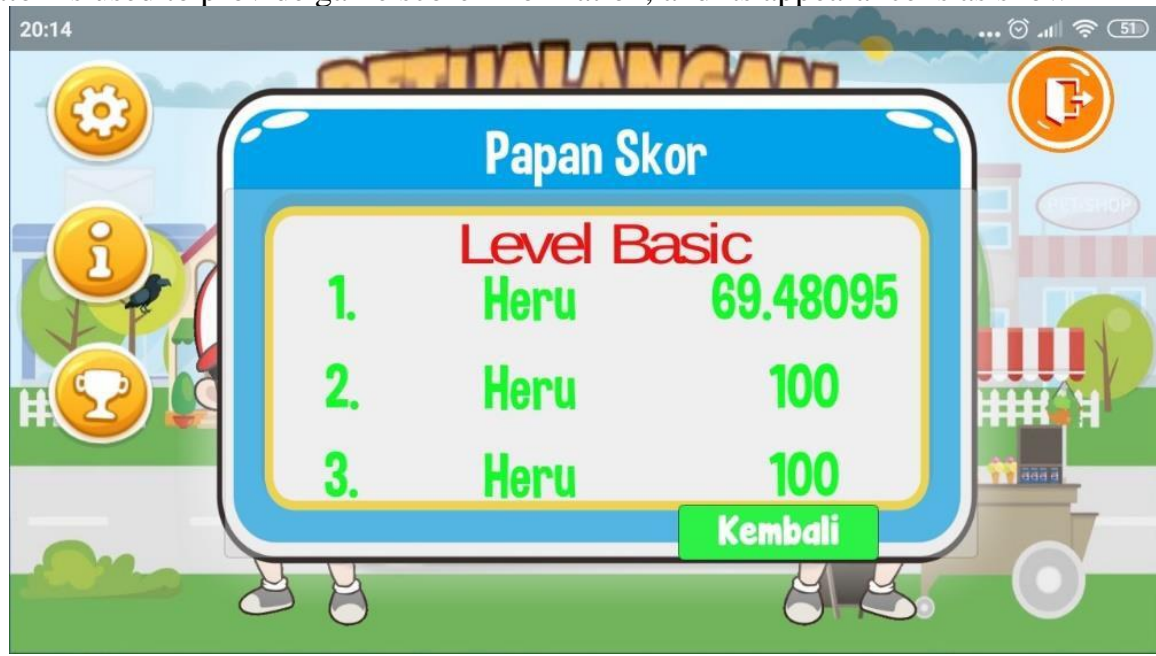

Figure 10. Level page

d. Play button, This button is used to enter and start game play

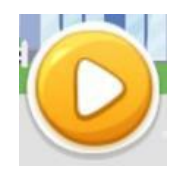

e. Exit button, This button is used to exit the game.
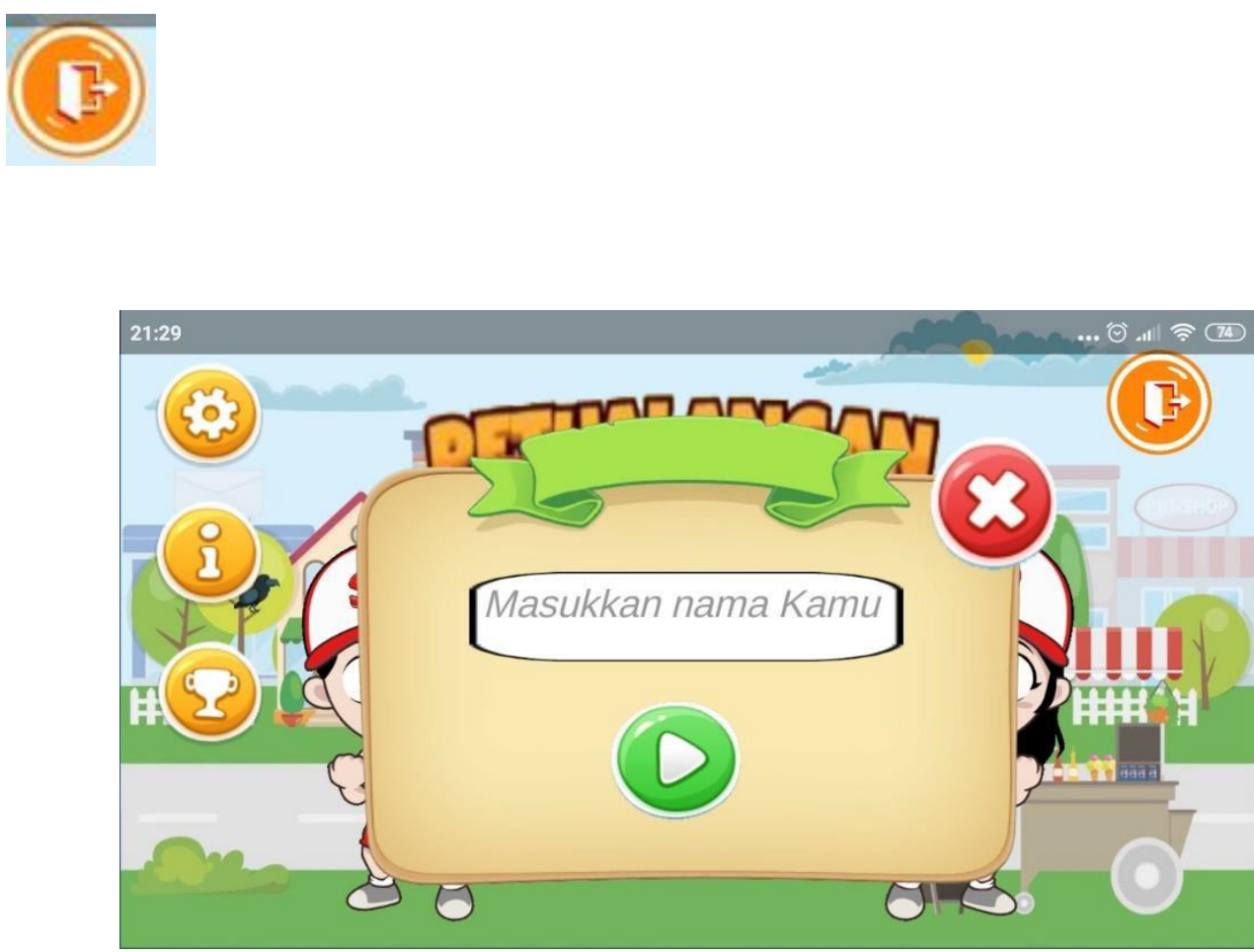

Figure 11. Name page 
This page is used to enter the name of the user playing the game. The display is as shown in Figure 11.

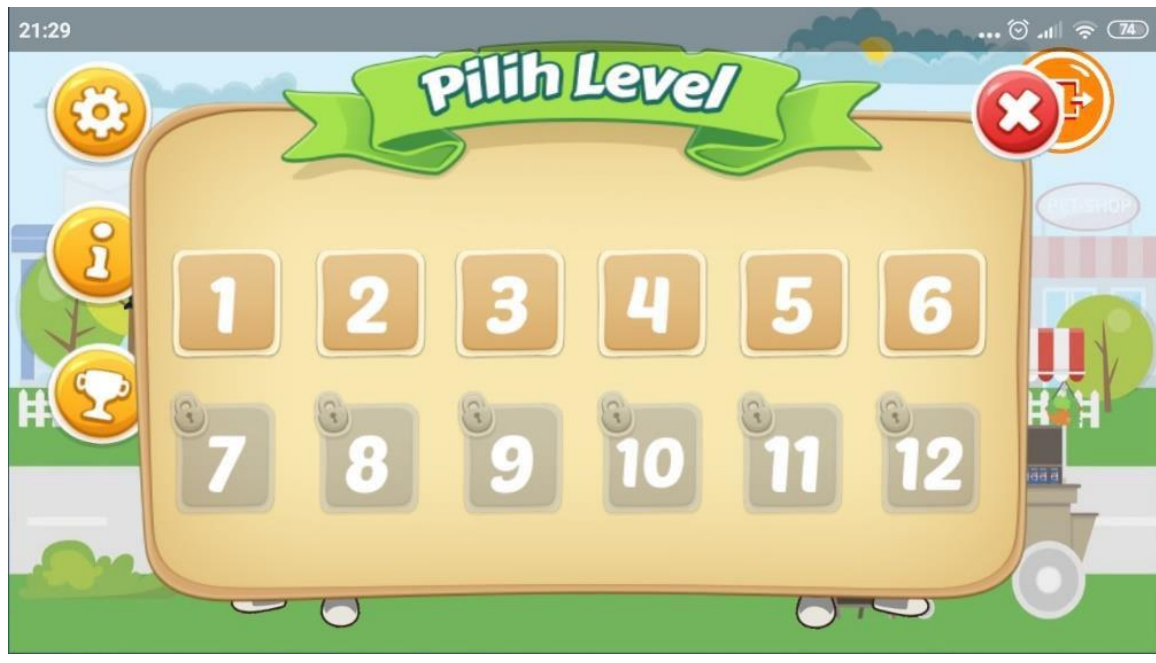

Figure 12. Level page

This page is used to select the game level. The display is as shown in Figure 12.

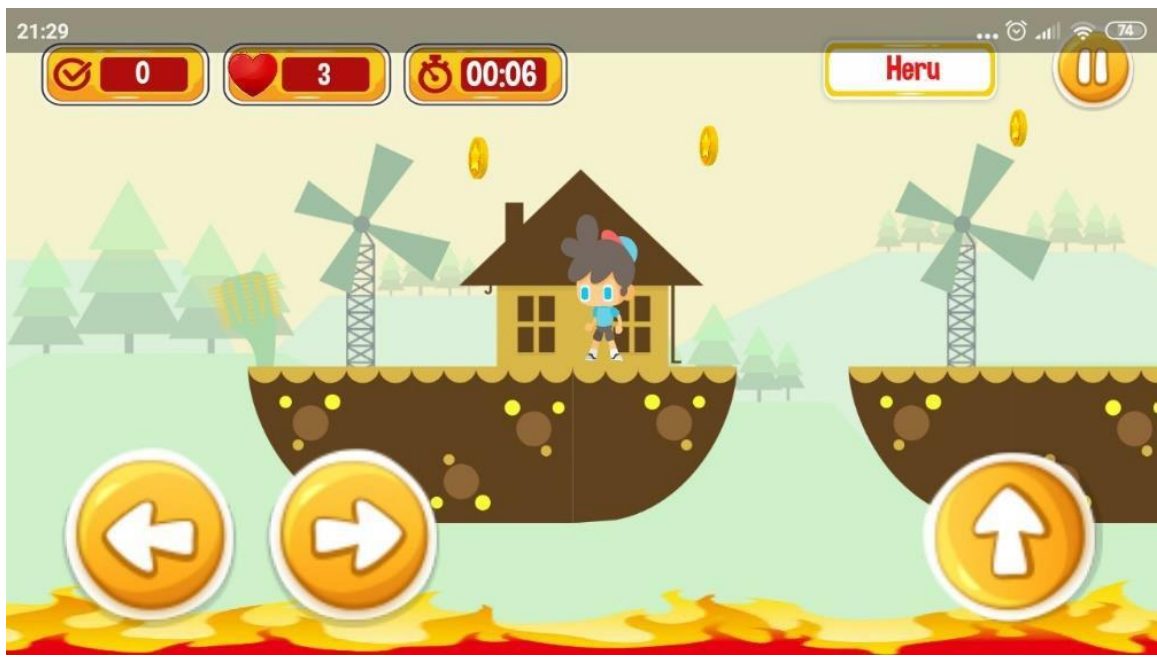

Figure 13. Game page

This page is a display when the game has started and will be played by the user, the display is as shown in Figure 13 above.

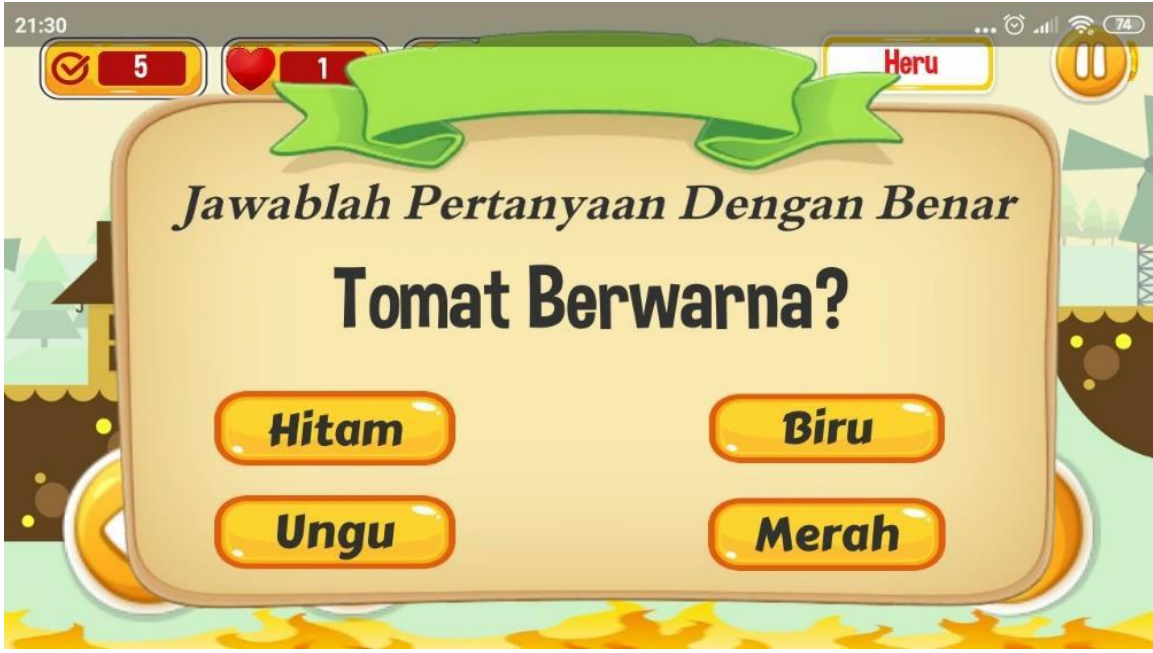

Figure 14. Question page 
f. This page is used to answer questions that arise when the player manages to take stars. The display is as shown in Figure 14.

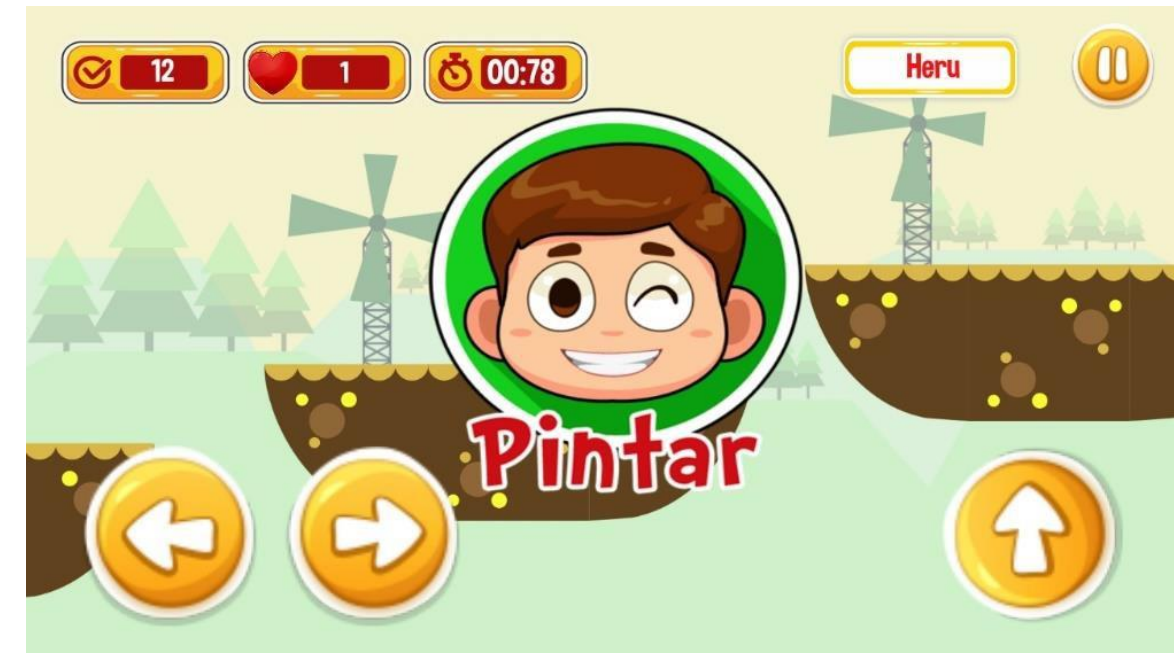

Gambar 15. True page

This page will appear when the player has successfully answered the question correctly. The display is as shown in Figure 15.

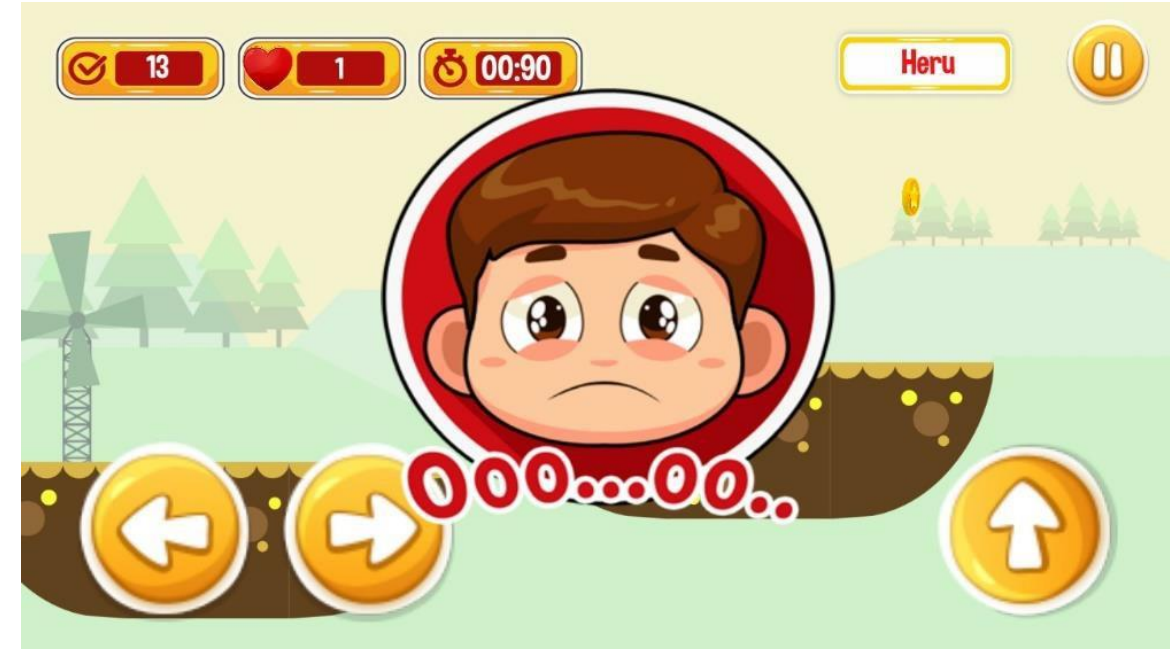

Figure 16. Incorrect Page

This page will appear when the player is unable to answer the question correctly. The display is as shown in Figure 16 .

\section{CONCLUSION}

Based on the results and discussion that has been done, it can be concluded that an Andorid-based game has been developed in the Unity application with the Protyping method with several resistance and designs that have been discussed and agreed upon by the user, and can run well on Android devices..

\section{REFERENCES}

[1] D. Purnomo, "Model Prototyping Pada Pengembangan Sistem Informasi," Jimp - Jurnal Informatika Merdeka Pasuruan, Vol. Vol.2 , No. No.2, Pp. 54-61, 2017.

[2] R. A. Rahman And D. Tresnawati, "Pengembangan Game Edukasi Pengenalan Nama Hewan Dan Habitatnya Dalam 3 Bahasa Sebagai Media Pembelajaran Berbasis Multimedia," Jurnal Algoritma, Vol. Vol. 13 , No. No. 1, Pp. 184-190, 2016.

[3] W. Nugraha And S. Muhamad, "Penerapan Metode Prototype Dalam Perancangan Sistem Informasi Penghitungan Volume Dan Cost Penjualan Minuman Berbasis Website," Jusim (Jurnal Sistem Informasi Musirawas), Vol. Vol 03 , No. No.02, Pp. 97-105, 2018. 
[4] R. Meimaharani And T. Listyorini, "Purwarupa Game Edukasi Pengenalan Warna Berbasis Android," Systemic, Vol. Vol. 1, No. No. 2, Pp. 27-31, 2015.

[5] A. Susanto And M. Meiryani, "System Development Method With The Prototype Method," International Journal Of Scientific \& Technology Research, Vol. 8, No. 07, Pp. 141-144, 2019.

[6] A. . A. Pradipta, Y. A. Prasetyo And N. Ambarsari, "Pengembangan Web E-Commerce Bojana Sari Menggunakan Metode Prototype," E-Proceeding Of Engineering, Vol. 2, No. No.1 , Pp. 1042-1056, 2015.

[7] E. Prasetya And A. Sugara, "Android Game "Shoot The Alien" Design And Development Using Prototyping Method," In Seminar Nasional Informatika Dan Sistem Informasi, Palembang, 2017.

\section{BIOGRAPHY OF AUTHORS (10 PT)}

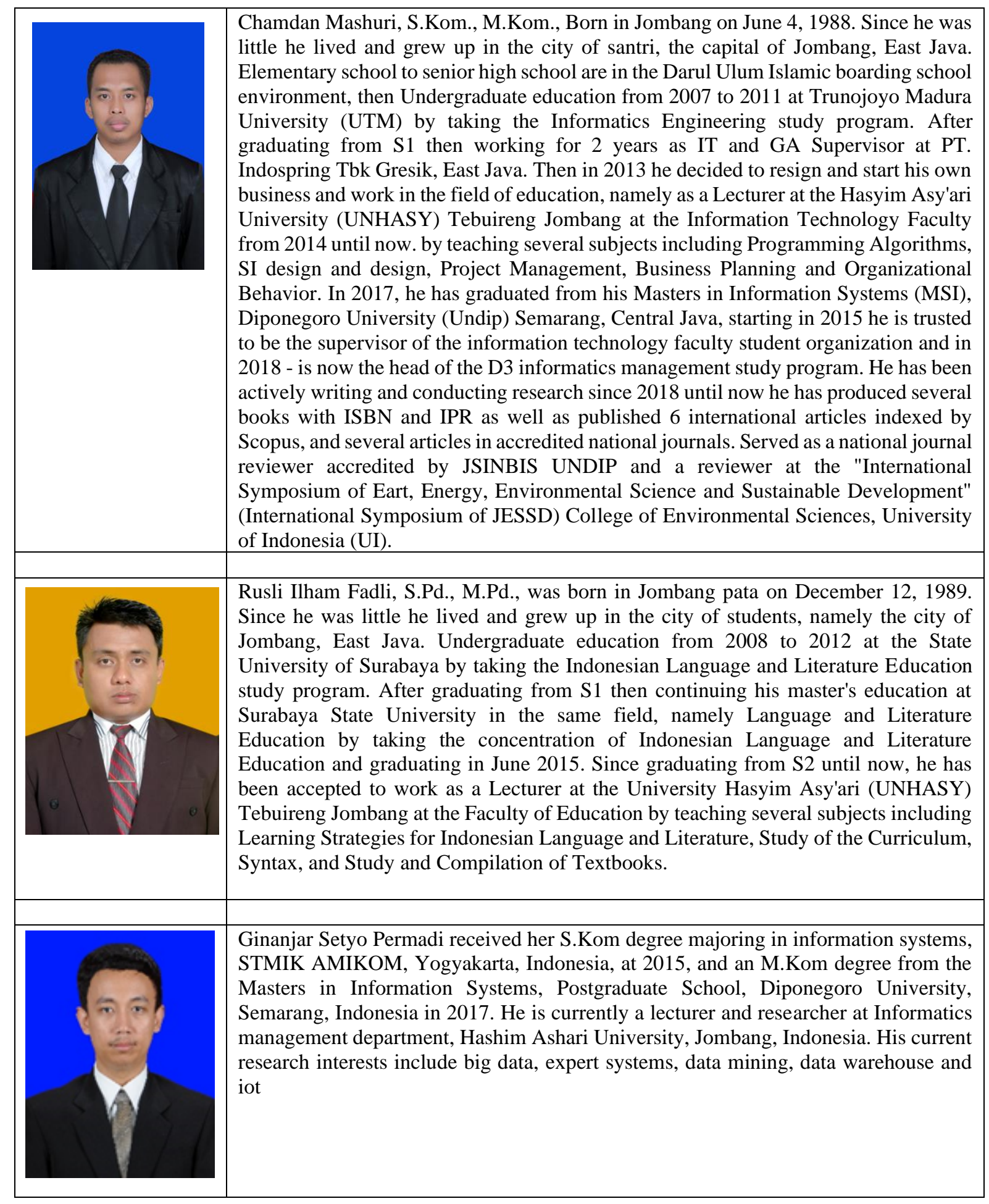


Developing Indonesian Learning Game Applications for Elementary School Students Using the Prototyping Method

\begin{tabular}{|l|l|}
\hline & \\
\hline & $\begin{array}{l}\text { Ahmad Heru Mujianto, S.Kom., M.Kom., Was born in Jombang July 24, 1992. Since } \\
\text { he was little he lived and grew up in the city of students, namely the city of Jombang, } \\
\text { East Java. Undergraduate education from } 2010 \text { to } 2014 \text { at the Darul 'Ulum Islamic } \\
\text { Boarding School (Unipdu) Jombang by taking the Information Systems study } \\
\text { program. After graduating from S1 then working for 1 year as administrative staff at } \\
\text { Unipdu Jombang. Then in September 2015 he decided to resign and continue his } \\
\text { postgraduate education at Amikom University Yogyakarta by taking the Information } \\
\text { Systems concentration and graduating in April 2017. Since graduating from S2 until } \\
\text { now, he was accepted to work as a Lecturer at the Hasyim Asy'ari University } \\
\text { (UNHASY) Tebuireng Jombang in The Faculty of Information Technology by } \\
\text { teaching several subjects including Object Oriented Programming, Operating Systems, } \\
\text { Digital Literacy, Web Programming and Computer Networks. }\end{array}$ \\
\hline
\end{tabular}

